\title{
Towards a Sustainable Solution: Factors and Prerequisites of Improving the Kanchan Arsenic Filters used in the Terai of Nepal. A Review
}

\author{
Barbara Mueller* \\ Bamugeobiochem, Horbenstrasse, Ettenhausen, Switzerland
}

*Corresponding Author: Barbara Mueller, Bamugeobiochem, Horbenstrasse, Ettenhausen, Switzerland

\begin{abstract}
The issue concerning the high arsenic concentrations in ground water used as drinking water in the lowland of Nepal was neglected for a long time. Whereas mainly Bangladesh received much international attention and support to develop appropriate filters to remove As, in Nepal the installation of the so called Kanchan filters only begun in the early nineties when adverse health effects were already observed. Arsenic itself can be readily released into ground water depending on $\mathrm{pH}$, redox conditions, temperature, and solution composition. Moreover, the widely spread hypothesis asserts that reductive dissolution of Fe-bearing minerals releases As-oxyanions. However, there is an obvious de-coupling of As and Fe concentrations in ground water resulting in loss of correlation concerning these two elements.Beyond that, As is positively correlated with $\mathrm{Na}$ and $\mathrm{K}$, the molar ration of Fe/As in the ground water is very low and in conclusion therefore clay minerals (containing a minor amount of $\mathrm{Fe}$ in their structure) haveto be regardedas a substantial host of As.In this regard, the partial low removal efficiency of the installed Kanchan filters can tentatively be explained by the ratio of main and trace elements (particularly $\mathrm{Fe}$ and As), pH, flow rates, contact time with the nails, and filter maintenance. This review summarizes the identified geological background, origin of the As, the established mitigation option and future improvements of the filters.
\end{abstract}

Keywords: Arsenic, iron, de-coupling, clay minerals, Kanchan filter, removal

\section{INTRODUCTION}

Unfortunately, Nepal's current arsenic issueconcerning ground water was recognized much later than in other countries of South-Asia (e.g. West Bengal (India), Bangladesh, Cambodia, Vietnam, China). Nepal did not seem to be much affected by As poisoning ground water hosted by quaternary alluvial sediments as the landlocked country is dominated by the mountain chain of the high Himalayas and only features a very narrow band of flat land (the so called Terai, the Indo-Gangetic Plain of southern Nepal) builtup by those quaternary alluvial sediments. The actual drinking water guideline $(10 \mu \mathrm{g} / \mathrm{l})$ for As imposed by the World Health Organization (WHO) is exceed in several districts (namely Nawalparasi, Bara, Parsa, Rautahat, Rupandehi, and Kapalivastu (Shrestha et al., 2014). As soon concentration of arsenic exceeds the guideline, detrimental health effects are likely to occur.Characteristic skin lesions including pigmentation changes (melanosis, keratosis); various reproductive, neurological, respiratory, cardiovascular, gastrointestinal and diabetic effects as well as cancers of almost all inner organsare among the most prominent health impacts caused by the longterm intake of As (Smith et al., 2000; Adhikari and Ghimire, 2009; Smith and Steinmaus, 2009; Abdul et al., 2015).

Sharma (1999) in a first report ever published mentioned arsenic contamination above toxic levels in ground water in the Terai Basin of Nepal. Later, Nakano et al. (2014) stated correctly that the population of the southern Indo-Gangetic Plain of Nepal (Terai) struggle with the same arsenic issue as do the inhabitants of Bangladesh, for example.But it was not before 2004 when Shrestha and Shrestha (2004)mentioned that twenty-four percent of ground water samples analyzed $(\mathrm{n}=18,635)$ from the Terai Basin exceeded the WHO limit of $10 \mu \mathrm{g} / \mathrm{L}$. According Panthi et al. (2006) 25,058 tube wells in the Terai region had been tested for As, of which 5,686 tube wells (22.7\%) exceeded the WHO (World Health Organization) As guideline (As $=0.01 \mathrm{mg} / \mathrm{L}$ ) and 1,916 tube wells $(7.6 \%$ ) exceeded the Nepal Interim As Standard (As $=0.05 \mathrm{mg} / \mathrm{L}$ ). In a first report compiled by NRCS- 
ENPHO (Nepal Red Cross Society/Environment \& Public Health Organization), 2002the prevalence of arsenicosis was indicated between $1.3 \%$ and $5.1 \%$ among four independent surveys. Approximately 0.5 million people in Terai were at risk of consuming ground water with an arsenic concentration $>50$ $\mu \mathrm{g} / \mathrm{L}$, the maximum permissible limit for Nepal (Shrestha et al. 2003). As a consequence of this alerts, in 2003, involving major stakeholders from the drinking water and sanitation sector, the National Arsenic Steering Committee (NASC) was established (Shrestha et al. 2003).

The element arsenic is mainly found in hydrous iron oxides and clay minerals. The toxic agent can easily be solubilized in groundwater depending on $\mathrm{pH}$, redox conditions, temperature, solution composition and climate. Source material of As contaminating water include: organic-rich or black shales, Holocene alluvial sediments with slow flushing rates, mining (most often gold deposits), volcanogenic sources, and also thermal springs. Two more environments can lead to high arsenic concentration in potable water: (i) closed basins in arid-to-semi-arid climates (especially in volcanogenic provinces) and (ii) strongly reducing aquifers, often composed of alluvial sediments but with low sulphate concentrations. Especially two triggers can initiate high dissolution of As (> 50 $\mu \mathrm{g} / \mathrm{L})$ : an increase in $\mathrm{pH}$ above 8.5 or the onset of reductive iron dissolution. High contents of phosphate, bicarbonate, silicate, and/or organic matter in the ground waters are other prime factors promoting arsenic solubility. The geologic and groundwater conditions triggering high arsenic concentrations are well known and help identify high-risk areas (Nordstrom, 2002; Smedley and Kinniburgh, 2002).

To eliminate arsenic from ground water so called Kanchan filters (KAF) were installed in Nepal. These filters were once developedas a joint venture between Massachusetts Institute of Technology (MIT), Environment \& Public Health Organization (ENPHO) and Centre for Affordable Water and Sanitation Technology (CAWST) (see Ngai et al. 2005, Ngai et al. 2006; Ngai et al. 2007). However, Sing et al. (2014) reported that unfortunately the long-term performance of those filters in Nepal had rarely been tested. The authors from the latter study clearly stated that out of the 41 tube exposing unsafe arsenic levels, KAFs reduced arsenic concentration to the safe level for only 22 tube wells. Therefore, 2015 an ongoing project to undoubtedly determine the geological background, effectiveness and improvement of the Kanchan filters used in the Terai was initiated by co-workers from CAWST in cooperation with ENPHO and Eawag, Switzerland. This review is primarily based on the work of Mueller (2017); Mueller, 2018; Mueller and Hug, 2018; Mueller (2019); Mueller (2019a); Mueller (2020); Mueller et al. (2020a) as since the publications of Ngai and co-workers (see Ngai et al. 2005, Ngai et al. 2006; Ngai et al. 2007) hardly any scientific articles were released internationally. For a detailed description of the arsenic issue in Nepal see Mueller (2017).

\section{Geological Situation ConCerning ARSEnic in Ground Water of the Terai}

Landlocked in South Asia, Nepal is principally mountainous, with approximately 6,000 rivers and rivulets, being the resources of extensive ground water reservoirs. The immense topographic variations in Nepal are largely controlled by geology (BGS, 2001; Thakur et al., 2011). The Himalayas presenting the prominent mountain chain in the country are built up by a wide range of various rocks of metamorphic, sedimentary, and igneous in origin. The heterogeneity concerning arsenic in ground water of the foreland is mainly caused by the huge variety of the source rocks (see Mueller, 2017). The Terai plain itself represents an active foreland basin consisting of Quaternary sediments including molasse units along with gravel, sand, silt, and clay.

These sedimentswith a high potential for ground water resources are replenished by a high monsoon precipitation (1,800-2,000 mm) and year-round snow-fed river systems.Over all, the geology of the Terai region is basically similar to the Bengal Delta Plain (BDP) and it is the continuation of IndoGangetic trough. For a detailed description of the geological background see (Mueller 2017).

Districts mostly affected by the arsenic issue in Nepal include Nawalparasi (Western Region), Rautahat and Bara (Central Region) and Bardia (Midwestern Region). The fine alluvial aquifers of Nawalparasi are among of the most severely As contaminated in the Terai region. This region is highly contaminated with As, unfortunately and predominantly determined as As(III), the more toxic form of arsenic.In the sediments of Nawalparasi district clays contain high amounts of iron and aluminum. Arsenic is as well abundantly incorporated in finer particles like clay minerals. Generally, higher concentrations of As were found mostly in the fine-grained clay sediments (black and yellow) 
Towards a Sustainable Solution: Factors and Prerequisites of Improving the Kanchan Arsenic Filters used in the Terai of Nepal. A Review

and to a lesser extent the in coarse-grained sediments(Yadav et al., 2015). Arsenic occurs typically in oxyanionic forms in the aqueous environment.Hydrogeochemical data for groundwater of the TAP (Terai Alluvial Plain) aquifers prove a predominantly reducing character, with high $\mathrm{HCO}_{3}^{-}$, low $\mathrm{SO}_{4}{ }^{2-}$, and $\mathrm{NO}_{3}{ }^{-}$concentrations.

\section{Mechanism of ArSenic Release to Groundwater}

The main mechanisms so far widely discussed and accepted was worked out by Nickson et al. (2000) in reference to the conditions in Bangladesh. The authors released the assertion that As in the groundwater originates from reductive dissolution of As-rich $\mathrm{Fe}$-oxyhydroxides existing as a dispersed phase (e.g. as a coating) on sedimentary grains. Furthermore, this reduction is reinforced by microbial degradation of sedimentary organic matter. There is a a widespread consensusthat the initial dominant process is the fixation of aqueous As by sorption onto Fe-, Mn-oxide or clay surfaces during high-redox medium-pH conditions (i.e. about 5.5-6.5). As a consequence of a rise in $\mathrm{pH}(\mathrm{pH}>6.5)$ and a negative Eh the desorptive release of arsenic occurs from sediment into ground water (Stanger 2005). Arsenic is generally found as the reduced trivalent form [As(III)] in ground water whereas the oxidized pentavalent form $[\mathrm{As}(\mathrm{V})]$, is present in surface water. Unfortunately, arsenite $[\mathrm{As}(\mathrm{III})]$ as well inorganic arsenic species are more toxic for living organisms than arsenate $[\mathrm{As}(\mathrm{V})]$ or organic forms of arsenic.Regarding ground water conditions in the Terai, Bhattacharya et al. (2003) report about a mostly near-neutral to alkaline $\mathrm{pH}$ range of 6.1-8.Redox potential (Eh) levels between -0.20 to $-0.11 \mathrm{~V}$ advocate fairly reduced condition in the aquifers. The groundwater is described as predominantly of $\mathrm{Ca}-\mathrm{Mg}-\mathrm{Na}-\mathrm{HCO}_{3}{ }^{-}$-type with $\mathrm{HCO}_{3}{ }^{-}$as the principal anion and low levels of $\mathrm{Cl}^{-}$and $\mathrm{SO}_{4}{ }^{2-}$. Panthi et al. (2006) as well as Diwakar et al. (2015) state that the low redox potential of tube well waters support the theory of reductive desorption, as some particular various redox sensitive elements (i.e. $\mathrm{Fe}^{2+}, \mathrm{As}(\mathrm{III}), \mathrm{NH}_{3}$ ) are very abundant in the aquifers of the Terai. The role of clay minerals as carriers of As is occasionally mentioned, as climatic variations in groundwater chemistry can serve to distinguish the contributions of the two sourcesin question (Fe-oxyhydroxides vs. clay minerals), and such variationsareparticularly pronounced in headwater areas of the Ganges floodplain immediately adjacent to the Himalayan foothills (e.g. the Terai of Nepal) (see e. g. Brikowski et al. 2014; Guillot et al, 2015).In the district of Nawalparasi most tube wells are drilled $20 \mathrm{~m}$ below ground level in order to exploit permanently saturated thin sandy layers. At this depths solid phase As(III) and lower valency As-sulphide species are recognized to be the dominant species, while poorly crystalline $\mathrm{Fe}(\mathrm{III})$ and Fe oxides are largely absent (Gurung et al., 2005).

In opposition to the above mentioned theory of microbially mediated reductive dissolution of As-rich Fe-oxyhydroxides, the role and influence of As bound and released from phyllosilicates (e. g. micas) was hardly ever discussed (see e. g. Stanger, 2005; Chakraborty et al., 2007; Charlet et al., 2005; Charlet et al.,2011; Brikowski et al., 2014; Guillot et al., 2015; Yadav et al., 2015; Uddin, 2017; Verma et al., 2016).In this regard, a striking feature of the ground water exploited in the Terai (as compared to the concentration of $\mathrm{Fe}$ and As in ground water from Bangladesh or Vietnam) is the very low average molar ratio Fe/As. In Vietnam the average molar ration of Fe/As fluctuates between 60 and 68 (Berg et al., 2008) whereas the ratio sums up to 14.88 or 90.49 in Bangladesh (Ahmed et al., 2010; Rahman et al., 2015). In contrast to this numbers the average molar Fe/As ratio for the 35 samples analyzed adds up to 9.4 (post-monsoon) and to 6.0 (pre-monsoon) in Nepal (Mueller and Hug, 2018). Moreover, there is a distinct decoupling (lack of correlation) of the concentration between $\mathrm{Fe}$ and $\mathrm{As}$ in the ground water in Nawalparasi.This decoupling obviously warrants the necessity to rethink the original mineralic hosts of arsenic and to include the absorption, incorporation and release of As from clay minerals.Diagrams presented in Mueller and Hug (2018) and Mueller (2019) unambiguouslydepict the correlation between between As and the lithophile elements $\mathrm{Na}, \mathrm{K}$, $\mathrm{Ca}, \mathrm{Mn}, \mathrm{Li}, \mathrm{B}, \mathrm{Sr}$ and $\mathrm{Mo}$. $\mathrm{Na}, \mathrm{Mg} \mathrm{K}$ and $\mathrm{Sr}$ (a replacement of $\mathrm{Na}$ and $\mathrm{K}$ ) can easily be dissociates from interlayers of phyllosilicates, $\mathrm{Na}, \mathrm{K}$ and $\mathrm{Sr}$ as well from alkali feldspars. Li, B and Mo are typical trace elements found in various forms of micas, $\mathrm{Li}$ and $\mathrm{B}$ represent major components of tourmaline (general formula: (Ca,K, Na)(Al,Fe, $\mathrm{Li}, \mathrm{Mg}, \quad \mathrm{Mn})_{3}(\mathrm{Al}, \mathrm{Cr}$, $\left.\mathrm{Fe}, \mathrm{V})_{6}\left(\mathrm{BO}_{3}\right)_{3}(\mathrm{Si}, \mathrm{Al}, \mathrm{B})_{3} \mathrm{O}_{18}(\mathrm{OH}, \mathrm{F})_{3}\right)$. Stueben et al. (2003) report about tourmaline- 
containingaquifers enriched in As in West Bengal, India. Mueller (2018)relates the typical trace element composition of ground water in the Terai to the origin of the soil minerals being transported from tertiary leucogranites (rich in B) in the High Himalayas.To convincingly complete the overall situation in the Terai regarding the mineralic host of As Zweifel (2018) hardlydetected any $\mathrm{Fe}(\mathrm{III})$ hydr(oxides) by X-ray analysis in a drill core from the district Nawalparasi - as opposed to abundant clay minerals in the same drill core.

In addition to the considerations above Guillot et al. (2015) reported about an apparent correlation concerning late Quaternary ( 0.5 - 1.0 million years b.p.) climate conditions and the concentration of arsenic in the alluvial sediments with As to be dominantly accumulated in sediments deposited during more arid periods. In humid periods the lower arsenic contents in sediments can be interpreted by leaching from sandy and silty sediments due to intensive monsoon rainfall. But according Mueller and Hug, (2018); Mueller (2019); Mueller (2019a) it was not possibleto find a prominent difference concerning As in ground water between climatic seasons. In contrast, the concentration of As in postmonsoon seems to be potentially higher than in pre-monsoon season. Yet the huge variation of As concentrations in ground water mirror the heterogeneous sediment composition in the district of Nawalparasi on a municipality-scale as well as the changes over time in redox conditions, $\mathrm{pH}$ and temperature. Guillot et al. (2015) already noted that As concentrates explicitly in the clay-dominated sediments in the Terai and is usuallycorrelated with specific elements ( $\mathrm{l}, \mathrm{K}$ and $\mathrm{C}$ ) and also mentioned a rather good correlation between $\mathrm{K} 2 \mathrm{O}$ and arsenic content in finer clay fractions, suggesting that biotite contributed to the fixation of this element.

\section{KANCHAN FilTERS AND THEIR CONSTRAINTS}

The aforementioned low concentration of $\mathrm{Fe}$, the low molar ratio of $\mathrm{Fe} / \mathrm{As}$ as well a general short residence time of the ground water within the nail bed of the filters, high $\mathrm{pH}$ and high concentrations of As, Na, B, Mo and other trace elements (see Mueller \& Hug, 2018) clearly limit the performance of the filters. A dry nailbed instead of a permanent immersion of the nails in ground water is another adverse effect concerning the removal efficiency of the filters used in Nawalparasi. A wet nail bed secures the formation of $\mathrm{Fe}$ (III)hydr(oxides), black mixed Fe(II,III)-phase solids and finally to conversion of the latter to magnetite $\left(\mathrm{Fe}_{3} \mathrm{O}_{4}\right)$ with integration of $\mathrm{As}(\mathrm{V})$ exhibiting a stronger adsorption affinity for $\mathrm{As}(\mathrm{V})$ than for $\mathrm{As}(\mathrm{III})$ (Wenk et al. 2014).X-ray examinations of nails from some of the monitored filters exhibits siderite $\left(\mathrm{FeCO}_{3}\right)$ on their surface. As this mineral is precipitated in reducing environments and therefore contains Fe(II) the indication is two fold: (i) the oxidation process in order to enhance rusting of the nails is incomplete and (ii) siderite inhibits the adsorption of As on the nail surfaceor co-precipitating with Fe(III)hydr(oxides) (Wenk et al., 2014; Guo et al., 2007).Analysis of the X-ray data undoubtedly reveal that siderite is dominantly formed on nails in contact with ground water with a high iron concentration. Therefore it is vital to enhance to contact time within the nail bed in order to prevent the precipitation of siderite (see also Mueller, 2019).

\section{FaCtORS INFLUENCING THE REMOVAl EFFICIENCY OF THE KANCHAN FILTERS}

Since the first field campaign in autumn 2015 at least 30 filters were inspected regularly and ground water samples were collected in pre-monsoon and post-monsoon seasons. The removal efficiency from those filters vary in a wide range from $5.81 \%$ to $97.1 \%$ (for details see Mueller, 2020); Mueller et al., 2020a).

There are several reasons found to influence the removal efficiency:

- Partially complete and dry nail bed or an irregular surface of the the bed (promoting channels were ground water can easilyflow without contact to the nails).

- Due to incomplete oxidation of the ground water flowing through the nail bed, siderite $\left(\mathrm{FeCO}_{3}\right)$ could be formed on the nail surfaces leading to a diminished adsorption of As. Unfortunately siderite is mainly formed on nails when the iron concentration of the ground water is high.

- Prolongated contact time (up to $30 \mathrm{~min}$ ) between the nails and the ground water ensured sufficient removal of high concentrations of As despite low concentrations of Fe. 
- Long-term (year-long) use of the lower sand layer leading to a reduced capacity of the fine grained sand (grain size $<2 \mathrm{~mm}$ ) to remove exfoliated particles with adsorbed As from the nails above.

\section{RESULTS OF THE FIRST STEP OF IMPROVEMENTS}

As a consequence of the above mentioned effect in 2018 and 2019 a first sand layer just above the nail bed was set for 30 filters. This sand bed should lower the flow through rate as well as to increase the contact time between nails and ground water. The sand itself was separated from the nails by a cloth (cotton-polyester blend) in order to facilitate maintenance. This sand bed should prevent the nails from drying as well while keeping the nails in place impeding the formation of irregularities within the nail bed. Sampling of all the adapted filters in spring 2019 clearly indicated that most of the filters equipped with an upper sand layer exhibited an improved performance. Best removal rates were achieved when the nail bed was kept wet permanently but not immersed in water. This way the nails seen to be oxygenated best. As usually the lower sand bed is hardly ever replaced according testimonies by queried residents the performance is still not as high as expected.

\section{Summary and Future Perspective}

A low performance of some of the filters are usually caused by neglection (e. g. displacement of the nails in the nail bed after time, pouring water into the filter to speedy causing an uneven nail bed) and poor maintenance (e. g. omitting to change the nails and the fine sand in the lower sand layer regularly).

In order to extend the contact time between nails and ground water, a tap at the outlet or raising the the outlet of the plastic bucket to above the level of the nail bed will be installed in order to regulate the outflow. This way, the nails should be kept wet and oxic conditions will prevail in the nail bed. Nails and sand of both sand layers have to be replaced on a regular basis.

Lastly, as the most important action, regular and repeated proper instruction courses for the users of the Kanchan filters have to be established. So far, instructions for the users have been more or less neglected, leading to a poor understanding of the concerned residents in the Terai. According statements of residents often women are responsible for installation and maintenance of the filters. Proper instructions leading to a deeper understanding concerning use of the filters and adverse health effects of a prolonged intake of As from drinking water supports the empowerment of women in a third world country as well.

\section{ACKNOWLEDGEMENT}

I am much obliged to Dr. Stephan Hug and Thomas Rütimann, Eawag, Dübendorf for all analytical work as well as to Tommy Ngai from CAWST, Calgary, Canada; Bipin Dangol and Hari Boudhatoki ENPHO, Kathmandu, Nepal; Gyan Prakash Yadav, Parasi, Nepal and to Som Rai, Kathmandu, Nepal. This research was supported by various private foundations from Switzerland.

\section{REFERENCES}

[1] Abdul, K. S. M., Jaysinghe S. S., Chandana E. P. S., Jayasumana Ch., Mangala, P.\&De Silva, C. S. (2015). Arsenic and human health effects: A review. EnvironmentalToxicolology and Pharmacology, 40, 828-846.

[2] Ahmed, F., Hawa Bibi, M., Ishiga, H., Fukushima, T., Maruoka, T. (2010). Geochemical study of arsenic and other trace elements in groundwater and sediments of the Old Brahmaputra River Plain, Bangladesh. Environmental Earth Science 60, 1303-1316.

[3] Adhikari, H. J. \&Ghimire, T. R. (2009). Prevalence of arsenicosis in Ramgram municipality, Nawalparasi, Nepal. International Journal of Health Research2, 183-188.

[4] Berg, M., Trang, P. T. K., Stengel, C., Buschmann, J., Viet, P. H., Dan, N.V., Giger, W., Stüben, D. (2008).Hydrological and sedimentary controls leading to arsenic contamination of groundwater in the Hanoi area, Vietnam: The impact of iron-arsenic ratios, peat, river bank deposits, and excessive groundwater abstraction. Chemical Geology 249, 91-112.

[5] Bhattacharya, P., Tandukar, N., Neku, A., Valero, A. A., Mukherjee, A. B., \&Jacks, G. (2003). Geogenic arsenic in groundwaters from Terai Alluvial Plain of Nepal. Journal of Physics IV France 107,173-176.

[6] Brikowski, T. H., Neku, A., Shrestha, S. D. \& Smith, L. S. (2014). Hydrologic control of temporal variability in groundwater arsenic on the Ganges floodplain of Nepal. Journal of Hydrology 518(C), 342-353. 
Towards a Sustainable Solution: Factors and Prerequisites of Improving the Kanchan Arsenic Filters used in the Terai of Nepal. A Review

[7] Chakraborty, S., Wolthers, M., Chatterjee, D. \& Charlet, L. (2007). Adsorption of arsenite and arsenate onto muscovite and biotite mica. Journal of Colloid and Interface Science, 309, 392-401.

[8] Diwakar, J., Johnston, S. G., Burton,E. D., \&Shrestha, S. D. 2(015). Arsenic mobilization in an alluvial aquifer of the Terai region, Nepal. Journal of Hydrology Regional Studies 4(A), 59-79.

[9] British Geological Survey (BGS) Report (2001) Groundwater Quality: Nepal, 4pp.

[10] Charlet, L., Chakraborty, S., Varma, S., Tournassat, C., Wolthers, M., Chatterjee, D. \&Roman Ross, G. (2005). Adsorption and Heterogeneous Reduction of Arsenic at the Phyllosilicate-Water Interface.In Advances in Arsenic Research. Edited byP. A. O'Day, D.Vlassopoulos, X.Meng, and L. G. Benning. ACS Symposium Series; American Chemical Society: Washington, DC, pp. 41-59.

[11] Charlet, L., Morin, G., Rose, J., Wang, Y., Auffan, M., Burnol, A., \& Fernandez-Martinez A. (2011). Reactivity at (nano)particle-water interfaces, redox processes, and arsenic transport in the environment.ComptesRendus Geoscience, 343, 123-139.

[12] Guillot, S., Garçon, M., Weinman, B., Gajurel, A., Tisserand, D., France-Lanord, C., van Geen, A., Chakraborty, S.,Huyghe, P., Upreti, B. N. \& Charlet L. (2015). Origin of arsenic in Late Pleistocene to Holocene sediments in the Nawalparasi district (Terai, Nepal). Environmental Earth Science,DOI $10.1007 / s 12665-015-4277-y$.

[13] Guo, H., Stueben, D. \&Berner, Z. (2007). Adsorption of arsenic (III) and arsenic(V) from ground water using natural siderite as the adsorbent. Journal of Colloid and Interface Science 315, 47-53.

[14] Gurung, J. K., Ishiga, H. \& Khadka M. (2005). Geological and geochemical examination of arsenic contamination in groundwater in the Holocene Terai Basin, Nepal. Environmental Geology 49, 98-113.

[15] Mueller, B.(2017). Arsenic in groundwater in the southern lowlands of Nepal and its mitigation options: A review. Environmental Reviews 25, 296-305.

[16] Mueller, B. (2018). Preliminary trace element analysis of arsenic in Nepalese groundwater may pinpoint its origin. Environmental Earth Sciences, 77, 35-40.

[17] Mueller, B. \& Hug, S. J. (2018). Climatic variations and de-coupling between arsenic and iron in arsenic contaminated ground water in the lowlands of Nepal. Chemosphere210, 347-358.

[18] Mueller, B. (2019). Ground water contamination by arsenic in Nepal: Lessons to be learned from geology. Austin Chemical Engineering 6,1064-1069.

[19] Mueller, B. (2019a): Trace element concentrations in arsenic contaminated drinking water in Nepal reflect surface-ground water interactions. Journal of Development Innovations 3, 12-28.

[20] Mueller, B. (2020): First results of improved arsenic removal by redesigned Kanchan filters in the lowlands of Nepal. Journal of Chemistry and Applications 2, 1-9.

[21] Mueller, B., Dangol, B., Ngai T. K. K.\&Hug S. J. (2020a). Kanchan arsenic filters in the lowlands of Nepal - mode of operation, arsenic removal and future improvements. Submitted to: Environmental Geochemistry and Health.

[22] Nakano, A., Kurosawa, K., Shamim, U. Md., and Tani, M. 2014. Geochemical assessment of arsenic contamination in well water and sediments from several communities in the Nawalparasi District of Nepal. Environmental Earth Science 72, 3269-3280.

[23] Ngai, T. K. K., Dangol, B., Murcott, S., \& Shrestha, R.R. (2005). Kanchan Arsenic Filter. Massachusetts Institute of Technology (MIT) and Environment and Public Health Organization (ENPHO). Kathmandu, Nepal. Booklet published by: Environment and Public Health Organization (ENPHO).

[24] Ngai, T. K. K., Murcott, S. E., Shrestha, R. R., Dangol, B., \&Maharjan, M. (2006). Development and

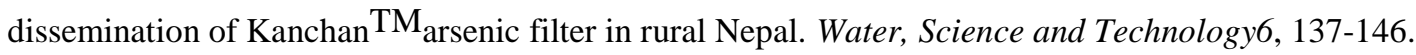

[25] Ngai, T. K. K., Shrestha, R. R., Dangol, B., Maharjan, M., \&Murcott, S. E. (2007).Design for sustainable development - Household drinking water filter for arsenic and pathogen treatment in Nepal. Journal of Environmental Science and Health - A. Toxic/Hazardous Substances Environmental Engineering42, 18791888.

[26] Nickson,R. T., McArthur,J. M., Ravenscroft,P., Burgess,W. G., and Ahmed, K. M. 2000. Mechanism of arsenic release to groundwater, Bangladesh and West Bengal. Appl. Geochem. 15(4): 403-413.

[27] NRCS-ENPHO 2002. Report on the household survey on the health impact of arsenic contaminated ground water in Bara district. A mimeographed report. Drinking water quality improvement program, Kathmandu, Nepal.

[28] NRCS-ENPHO 2003. An overview of arsenic contamination and its mitigation in Nepal Red Cross Society Program Areas ( Jhapa, Sarlahi, Saptari, Bara, Parsa, Rautahat, Nawalparasi, Rupandehi, Kapilvastu, Banke and Bardiya) Drinking Water Quality Improvement Program. Nepal Red Cross Society/ Japanese Red Cross Society/ ENPHO., Kathmandu, Nepal. 
Towards a Sustainable Solution: Factors and Prerequisites of Improving the Kanchan Arsenic Filters used in the Terai of Nepal. A Review

[29] Nordstrom, D. K. 2002. Worldwide occurrences of arsenic in groundwater. Science 296, 143-145.

[30] Panthi, R. S,. Sharma, S.\& Mishra, K. A. (2006). Recent status of Arsenic contamination in groundwater of Nepal - A review. Kathmandu University Journal of Science, Engineering and Technology 2, 1-11.

[31] Rahman, M., Dong, Z., Naidu, R.. (2015). Concentrations of arsenic and other elements in groundwater of Bangladesh and West Bengal, India: Potential cancer risk. Chemosphere 139,54-64.

[32] Sharma, R. M. 1999. Research study on possible contamination of groundwater with arsenic in Jhapa, Morang, and Sunsari districts of Eastern Terai of Nepal. Report of WHO Project, DWSS Government of Nepal.

[33] Shrestha, B. R., \&Shrestha, K. B. (2004). Spatial distribution of arsenic concentration in groundwater in the Terai, Nepal. In Summary Project Report. Edited by D. R. Kansakar. Department of Irrigation, Lalitpur, Nepal, HMG/Nepal, pp. 85-96.

[34] Shrestha, R. K., Regmi, D.\&Kafle, B. P. (2014).Seasonal variation of arsenic concentration in groundwater of Nawalparasi district of Nepal. International Journal of Applied Science and Biotechnology2,59-63.

[35] Shrestha, R. R., Shrestha, M. P., Upadhyay, N. P., Pradhan, R., Khadka, R., Maskey, A., Tuladhar, S., Dahal, B. M., Shrestha, S., and Shrestha, K. 2003. Groundwater arsenic contamination in Nepal: A new challenge for water supply sector. In Arsenic Exposure and Health Effects. Edited by W. R. Chappell, C. O. Abernathy, R. L. Calderon, and D. J. Thomas. Elsevier B.V., pp. 25-37.

[36] Singh, A., Smith, L. S., Shrestha, S., \&Maden, N. (2014). Efficacy of arsenic filtration by Kanchan Arsenic Filter in Nepal. Journal of Water and Health 12,596-599.

[37] Smedley, P. K.\&Kinniburgh D. G. (2002). A review of the source, behaviour and distribution of arsenic in natural waters. Applied Geochemistry 17, 517-568.

[38] Smith, A. H. \& Steinmaus, C. M. (2009) Health Effects of Arsenic and Chromium in Drinking Water: Recent Human Findings. Annual Reviews in Public Health 30, 107-122.

[39] Smith, A. H., Lingas, E. O.\&Rahman M. (2000). Contamination of drinking-water by arsenic in Bangladesh: a public health emergency. Bulletin of the World Health Organization78,1093-1103.

[40] Stanger, G. 2005. A palaeo-hydrogeological model for arsenic contamination in southern and south-east Asia. Environmental Geochemistry and Health 27, 359-367.

[41] Stueben, D., Berner, Z., Chandrasekharam, D. \& Karma, J. (2003). Arsenic enrichment in groundwater of West Bengal, India: geochemical evidence for mobilization of under reducing conditions. Applied Geochemistrym18,1417-1434

[42] Thakur, J. K., Thakur, K. R., Ramanathan, A., Kumar, M., \& Singh, S. K. (2011). Arsenic contamination of Groundwater in Nepal - An overview. Water 3, 1-20.

[43] Uddin, M.K. (2017). A review on the adsorption of heavy metals by clay minerals, with special focus on the past decade. Chemical Engineering Journal 308, 438-462.

[44] Verma, S., Mukherjee, A., Mahanta, C., Choudhury, R. \&Mitra, K. (2016). Influence of geology on groundwater-sediment interactions in arsenic enriched tectono-morphic aquifers of the Himalayan Brahmaputra river basin.Journal of Hydrology540, 176-195.

[45] Wenk, C., Kaegi, R., \& Hug, S. J. (2014). Factors affecting arsenic and uranium removal with zero-valent iron: laboratory tests with Kanchan-type iron nail filter columns with different groundwaters. Environmental Chemistry 11, 547-557.

[46] Yadav, I. C., Devi, N. L.\& Sing S. (2015). Reductive dissolution of iron-oxyhydroxides directs groundwater arsenic mobilization in the upstream of Ganges River basin, Nepal. Journal of Geochemical Exploration 148,150-160.

[47] Zweifel, E. R. (2018). Arsenic contamination in Nepal: Water treatment issues and geologic origin of the pollution. Master Thesis, Institute of Geography, University of Bern, 67 pp.

Citation: Barbara Mueller, "Towards a Sustainable Solution: Factors and Prerequisites of Improving the Kanchan Arsenic Filters used in the Terai of Nepal. A Review", International Journal of Advanced Research in Chemical Science, 7(5), pp. 1-7. DOI: https:// doi.org/10.20431/2349-0403.0705001

Copyright: () 2020 Authors, This is an open-access article distributed under the terms of the Creative Commons Attribution License, which permits unrestricted use, distribution, and reproduction in any medium, provided the original author and source are credited. 